\title{
An Empirical Research on Impact of HRD Climate on Infosys Pune
}

\author{
Geetanjali Bhambhani \\ Sushila Devi Bansal College of Engineering, Indore (MP) \\ Monica Sainy \\ Shri Vaishnav Vidyapeeth Vishwavidyalaya, Indore (MP) \\ Rajiv Gupta \\ Institute of Management Studies, Indore (MP)
}

\begin{abstract}
In current scenario of ever changing surroundings IT sector is an emergent and mounting solitary. IT sector being a part Service industry is extreme lyreliant on the proficiencies and enthusiasm of recruits. Thus it's momentous to investigate Human Resource Development which is comprised of two elements i.e., climate and culture of such organizations. The current research is an attempt to identify the HRD-climate practices in Infosys Pune. The investigator has used standardized planned opinionaire together information from the 50 employees of Infosys opinionaire.The information collected was analyzed by applying Factor analysis, Friedmen-test, one-way anova, Correlations and mean score. The main aim of present research was to examine the temperament of HRD-climate in Infosys and identify the factors conducive towards HRD-climate. Here researcher makes an effort to pull out notable HRD-Climate components derived from the inter-relationship of variables of HRD-Climate. Based on belief of Infosys employee's influence of HRD components is measured. The result of the study involves 50 respondents from Infosys. The correlation analysis it has been observed that all three components HRD Mechanisms, General climate and OCTAPACE Culture are highly correlated to each other the value of $r$ is lies 0.687 to 0.834 , which highlights that deviation in single component will have strong influence on other two components. HRD-mechanisms is the top influencing element with mean score of 2.14. On account of overall result research determines that employees are motivated in their organisation, there is high level of team spirit and employees are encouraged to bring creative ideas and are supported by top management of organisation.
\end{abstract}

Keywords: HRD-Climate, organizational culture; Factor analysis, Correlation, Infosys, Employees.

\section{INTRODUCTION}

In cut throat competition only those IT businesses will survive and thrive that have an edge over others in the resources they possess. In 1991, Barney it is gradually opposed that only businesses will be capable to meet-up confronts those get hold of and make the most of precious, inadequate and incomparable possessions. During 1998 Barney and Wright asserted that Human possessions can occupy predominantly assuming that workforces are productively utilised in the course of suitable HR convention and administration of organizational way of life. HR is strictly the utmost imperative reserve that any establishment

Journal of Technology Management for Growing Economies Vol. 9, No. 1 April, 2018 pp. 7-21

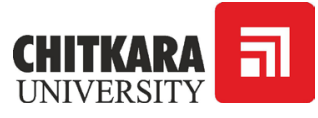

(C) 2018 by Chitkara University. All Rights Reserved. 
Bhambhani, G. acquire. They contribute to the Knowledge, social and mental asset of an Sainy, M. Gupta, R. association; as a rule vital instrument following each victory or let down. Thus, it is extremely essential to build up the capabilities of employees amid shifting era to maintain it in rapidity of competition. All IT industries introduce HRD in order to continue the man power at equivalence with constantly altering technology and promising challenge. All HR development sections hold responsibility of sustaining a solidify culture, ambience and working environment with company premises. Individuals' performance and contentment are highly influenced by culture of organization they are working in. A business establishment turn out to be vigorous and progress leaning if its folks are self-motivated and proactive. An association can create their work forces vibrant and proactive by selecting an appropriate individual and by fostering their enthusiasm and new proficiencies. In order to persist it's imperative for a business unit to embrace transformation in the surroundings and uninterruptedly convey their personnel to encounter the dares, that will lead a affirmative influence in the association.HR development is disturbed with an endowment of knowledge and advancement prospects which up keep the realisation of corporate policies and expansion of administrative, individual and team enactment (Armstrong and Baron, 2002)

\section{THEORETICAL CONCEPTS}

The genesis of Human Resource Development goes back to 19th century. When L. Nadler from George Washington University articulated notion of Human Resources Development, in 1970s during the conference organised by the American Society for Training and Development. He well-defined HRD as a sequence of systematized actions, directed within a specified span of time, and deliberate to yieldinteractivevariation. He also acknowledged certain common deeds in HRD asteaching, learning and enlargement.

HRD-climate plays main character in confirming the know-how, inspiration and improvement of organizational staffs. It is both a means as well as end itself. It expresses employees view towards the guidelines, processes, systems and circumstances that ensue in operational setting. HRD-Climate is enormously imperative for the definitive reaching of commercial objectives. In 1988, Athreya stated that: affirmative HRD-climate extracts the standing structures further active and creates the business additional can enable towards overview of pertinent supplementary scheme. Rao, 1992 indicated an association that devises healthier HRD-climate and progressions is probably to be more operative that an association doesn't possess. In an accumulation, HRD-climate has stayed conveyed a momentous conjecturer of professional efficacy.

Journal of Technology Management for Growing Economies, Volume 9, Number 1, April 2018 
HRD climate is characterised by OCTAPAC-culture, where O-stands for Openness, C-stands for Collaboration, T-stands for Trust, A-stands for Autonomy, P-stands for Proactivity, A-stands for Authenticity and C-stands for confrontation. Openness means that workforces' sense unrestricted to deliberate their thoughts, actions and moods with everyone. Collaboration is to admit association to support to every single individuals and strength as groups. Trust is captivating individuals at one on one and considering anything they express. Autonomy is providing liberty to occupancy folk's work individually with accountability. Pro-activity is inspiring personnel for takings inventiveness and possibilities. Authenticity is propensity in entities to ensure whatever they state. Confrontation is conveying complications and concerns with a sight to resolving them reasonably than smacking them in lieu of anxiety of broken-hearted or getting injured.

\section{STATEMENT OF THE PROBLEM}

Worldwidecut throat competition leads invention of innovative products and services and constantly varying technology have calls for well-developed and provoked human resources in IT Segment. The IT business is becoming progressively complex apparent of rising rivalry due to upcoming multinational projects. The key cost of the IT is the outlay on human aspect. The IT firms desires to slash this cost by rising the effectiveness and efficacy of human aspect that require an amiable development climate in the Software companies. This research is considered to inspect the existing HRD climate in Infosys i.e. which is renowned key player of IT sector.

\section{REVIEW OF LITERATURE}

$>$ Salokhe (2002) study revealed HRD climate in certain banks which exposed the survival of a extraordinarily noble HRD climate in the organized, public and co-operative banks.

$>$ M. Srimannarayana (2005) determined HRD climate was widespread in small trading units. He advised the units to announce employee welfare program and reward schemes fairly to develop employee gratification intensities and consequently to gain benefit from the gratified staffs to increase sales.

$>$ Mufeed (2006)carried out a research at Jammu and Kashmir for which he identified some hospitals namely Shri-Kashmir Institute of Medical Sciences (SKIMS) in relation to acuity of hospital employees with regard to HRD-. The findings of the research demonstrate the active HRD-climate in the hospital to a huge intensity is radically depressed. It also states that HRD prevailing in administration utilizes various instruments like perfor-
An Empirical

Research on

Impact of HRD 
Bhambhani, G. Sainy, M. Gupta, R. mance appraisal system, training, promotion, rewards, organisational improvement and counseling etc., in order to build anatmosphere favourable to accomplish organisational goals.

$>$ Battu (2007) conducted his study on HRD-Climate in Agri-gold Private Limited. He correlated the awareness of leaders, bosses and personnel on diverse category of common climate, OCTAPAC-culture and the common climate, HRD-Mechanisms and OCTAPAC-culture stand healthier in ITcompanieslinked to production companies. Based on the relation investigation, it is anecdotal that significant difference exists between both IT and production companies in regard to HRD-climate

$>$ Kumudha and Abraham (2008) stated that programs allied to self-development, job openings, and prospects to acquire new abilities and retirement provision programs prominently stimulate the emotional state of career gratification.

$>$ Saraswathi (2010) in her study concluded that considerable differentiations exist between both IT and Production companies in context to HRD-climate. The research highlights that HRD-climate for IT is superior to Production companies.

$>$ Dr. Birajit Mohanty (2012) the examination on "HRD-climate and how it influence work operation in Odisha insurance firms exclusively in private-one" has been undertaken with the objective, to ascertain level of HRD-climate among personnel working selected private insurance companies, to discover rapport of HRD-climate with its outcomes of a favourable HRD climate, to analyses influence of HRD-climate on work attainment of individuals.

$>$ Prof. IK. Kilam (2012) the study on Indian public sector banks focusing on "career forecasting along with HRD-climate as foremost HR confrontation" has been undertaken with the objective, to study and analyze the individual employee's own role in career planning and development, to study and analyze the organisational role in planning and development of careers of its people, to study and analyze the individual career planning experiences and bring out silent futures of such experiences.

$>$ Santosh K. Mohanty\& K. M. Sahoo (2012) established that reasonable HRD-climate stood dominant in IT companies. In assessment it has been observed that OCTAPAC-culture is further widespread in contrast to HRD-mechanism and common HRD-climate in IT sector.

$>$ Vaneet Kashyap, Prince Vohra, Tejbir Kaur (2012) found that HR experts/chief can deliberate personnel as essential investorto the extent that organisation values is stimulated. They also found that openness; authenticity, proactivity, confrontation, collaboration, trust,

Journal of Technology Management for Growing Economies, Volume 9, Number 1, April 2018 
experimentation and self-sufficiency don't vary considerably in 4 IT organisations.

$>$ Mufeed and Hamdani (2013) asserted HRD climate and HRD mechanisms are dissatisfactory in case of health care sector of Jammu and Kashmir.

$>$ Shweta Mittal (2013) the findings of the research were in finding the higher level management's backing towards progression of workforces, for which 12-objects were recognised as of the opinion poll in order to known the insight of examines of SBI and Axis bank was compared on the basis of general climate by using the T-test.

$>$ Tahir Ahmad Wani(July 2013) conducted a survey on experiential research of HRD-climate and OCTAPAC-culture of Indian FMCG firms with the objectives to scrutinize the inherent of HRD-climate and OCTAPACE-culture standing in organisation and checking impact of acquisition in Cadbury by Kraft foods on existing climate

$>$ Dr. Dolly Dolai (2015) research paper published in volume: 4, Issue: 7 conducted a study on"perception of employees on HRD climate in insurance sector", the intentions of research is to analyze HRD-climate of insurance companies for both private and public sector, and to understand the current position of HRD-climate.

\section{RESEARCH GAP}

Based on in-depth review of literature and considering diverse magnitude of HRD confers an impression that there are various gaps in this direction. It is observed that various studies referred in the previous sections were bound to elucidate other service and manufacturing sector like hospitality, banking, Insurance, FMCG etc. A scarcity of studies intended at exploring the overall HRD climate IT Sector for a longer time period are vastly common in nature. So far no study is done on HRD climate of Infosys. In consideration of this fact an effort has been made to study HRD Climate in Infosys.

\section{RESEARCH QUESTIONS}

1. How does HRD climate of Infosys influence its employee?

2. Which are the important attributes of HRD climate in Infosys?

3. Is there any significant difference in HRD climate based on respondents' demographic factors?

\section{OBJECTIVES OF THIS STUDY}

$>$ To investigate HRD-climate of Infosys Technologies Pune.

$>$ To examine variables contributing to HRD-Climate.

$>$ To acquire different aspects influencing HRD-Climate in Infosys

Journal of Technology Management for Growing Economies, Volume 9, Number 1, April 2018
An Empirical

Research on

Impact of HRD 
Bhambhani, G. Sainy, M. Gupta, R.
Technologies Pune

To scrutinize the environment of HRD-Climate and OCTAPACE Culture obtainable in Infosys Technologies Pune

\section{CONCEPTUAL FRAMEWORK}

In view of above discussion present research demonstrates framework to conduct research for studying how independent variable i.e. 1) HRD mechanisms; 2) Generalclimate; and 3) OCTAPAC- culture influence dependent variable i.e. HRD climate.

Independent Variables

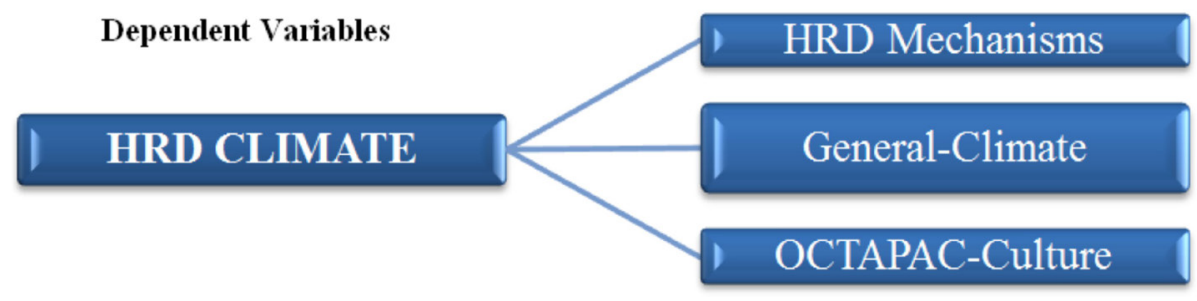

\section{DEVELOPMENT OF HYPOTHESIS}

$\mathbf{H}_{\mathbf{0}}$ : There is no significant relationship between HRD climate dimensions and demographic variables i.e age, gender, marital status, educational qualifications, Income and Experience.

$\mathbf{H}_{\mathbf{0}}$ : All three elements have equal impact of HR-climate in Infosys.

\section{SIGNIFICANCE OF THE STUDY}

An amiableHRD-climate stays exceptionally significant forcriticalaccomplishment of corporate objectives. With reference to theIndian outlook, nature of business affects the philosophy prevailing in the association. Subsequently environment is a result of values and beliefs, this research challenges to study HRD-climate in Infosys Pune. The current research tries to evaluate the magnitude of HRDclimate widespread in Infosys. 18-Elements of HRD-climate are grouped to form questionnaire, the three elements are: 1) HRD mechanisms; 2) General-climate; and 3) OCTAPAC-culture. The elements concerned to HRD mechanisms evaluate the level to which HRD-mechanisms is being executed completely. The generalclimate elements treat distinction specified to the HRD in all-purpose from upper and middle management. The OCTAPAC elements covers the magnitude to which openness, collaboration, trust, authenticity, pro-activity, autonomy and confrontation are esteemed and stimulated in Infosys.

\section{METHODOLOGY}

A research Methodology is the layout of research. It gives outline for sequence of setting for assortment and examination of facts. For this research, exploratory

Journal of Technology Management for Growing Economies, Volume 9, Number 1, April 2018 
research design concerned with defining the opinion of each individuals or narrating factors on HRD Climate management practices. It involves mostly quantitative and qualitative in nature with observable behaviors.

$>$ Research Design- The examination intention and inquiries discovered that this research is Exploratory in character.

$>$ Research Population-IT employees of Infosys Technologies Pune.

$>$ Sampling Technique-Non-Probability Convenience.

$>$ Sample Size-50

$>$ Sources of Facts-The data for the study have been collected through two sources - Primary Data and Secondary Data.

$>$ Data Analysis Software - IBM SPSS 20 version

> Methods of Data Analysis-Reliability, Factor Analysis, Correlation, Friedmen-test, One-way Anova, Mean Score.

\section{DATA TESTING AND ANALYSIS}

Table 1: Demographic Profiles

\begin{tabular}{|c|c|c|c|c|c|c|}
\hline \multicolumn{6}{|c|}{ Age } & Total \\
\hline 18-25years & 26-35years & \multicolumn{3}{|c|}{$36-45$ years } & & 50 \\
\hline $28(56 \%)$ & $15(30 \%)$ & \multicolumn{3}{|c|}{$7(14 \%)$} & & $(100 \%)$ \\
\hline \multicolumn{7}{|c|}{ Gender } \\
\hline \multicolumn{4}{|c|}{ Male } & \multicolumn{2}{|r|}{ Female } & \multirow{2}{*}{$\begin{array}{c}50 \\
(100 \%)\end{array}$} \\
\hline \multicolumn{4}{|c|}{$37(74 \%)$} & \multicolumn{2}{|r|}{$13(26 \%)$} & \\
\hline \multicolumn{7}{|c|}{ Marital Status } \\
\hline \multicolumn{4}{|c|}{ Married } & \multicolumn{2}{|r|}{ Unmarried } & \multirow{2}{*}{$\begin{array}{c}50 \\
(100 \%) \\
\end{array}$} \\
\hline \multicolumn{4}{|c|}{$16(32 \%)$} & \multicolumn{2}{|r|}{$34(68 \%)$} & \\
\hline \multicolumn{7}{|c|}{ Qualification } \\
\hline UG & Graduate & \multicolumn{2}{|c|}{ PG } & \multicolumn{2}{|c|}{ Diploma or Certificate } & \multirow{2}{*}{$\begin{array}{c}50 \\
(100 \%) \\
\end{array}$} \\
\hline $6(12 \%)$ & $22(44 \%)$ & $21(42$ & & & $1(2 \%)$ & \\
\hline \multicolumn{7}{|c|}{ Income in Rs. on monthly basis } \\
\hline $\begin{array}{l}\text { Below } \\
\text { Rs.10K }\end{array}$ & Rs. $10-20$ & $\begin{array}{l}\text { Rs. 20- } \\
30 \mathrm{~K}\end{array}$ & & & $\begin{array}{l}\text { Rs. Above } \\
40 \mathrm{~K}\end{array}$ & \multirow{2}{*}{$\begin{array}{c}50 \\
(100 \%)\end{array}$} \\
\hline $4(8 \%)$ & $16(32 \%)$ & $9(18 \%)$ & & $18 \%)$ & $12(24 \%)$ & \\
\hline \multicolumn{7}{|c|}{ Total Experience } \\
\hline $0-5$ years & \multicolumn{2}{|c|}{$5-10$ years } & & \multicolumn{2}{|c|}{ 10- 15 years } & \multirow{2}{*}{$\begin{array}{c}50 \\
(100 \%)\end{array}$} \\
\hline $35(70 \%)$ & \multicolumn{2}{|c|}{$9(18 \%)$} & & \multicolumn{2}{|c|}{$6(12 \%)$} & \\
\hline
\end{tabular}

Journal of Technology Management for Growing Economies, Volume 9, Number 1, April 2018
An Empirical

Research on Impact of HRD 
Bhambhani, G. RELIABILITY TEST

Sainy, M.

Gupta, R.

Table 2: Reliability Statistics

\begin{tabular}{|c|c|}
\hline Cronbach's Alpha & N of Items \\
\hline .928 & 18 \\
\hline
\end{tabular}

Interpretation: -Form the above table it is inferred that the coefficient of alpha value is 0.928 for 18 elements is reasonably extraordinary interior uniformity

\section{FACTOR ANALYSIS}

Factors analysis has been extracted by using principal component method and rotated by Kaiser-Varimax rotation method.

Table 3: KMO and Bartlett's Test

\begin{tabular}{|c|c|c|}
\hline \multicolumn{2}{|c|}{ Kaiser-Meyer-Olkin Measure of Sampling Adequacy. } & .822 \\
\hline \multirow{3}{*}{ Bartlett's Test of Sphericity } & Approx. Chi-Square & 521.640 \\
\cline { 2 - 3 } & $\mathrm{df}$ & 171 \\
\cline { 2 - 3 } & Sig. & .000 \\
\hline
\end{tabular}

Interpretation: the above reveals 0.822 as KMO-value. Similarly, Bartlett test of sphericity Chi-square measure is $\mathbf{5 2 1 . 6 4 0}$ and significance value is .000 which indicates factor analysis done with $\mathbf{3}$ variables consisting 18-element is effective.

Table 4: Factor Load

\begin{tabular}{|c|c|c|c|c|}
\hline $\begin{array}{l}\text { Factor } \\
\text { Name }\end{array}$ & Items & $\begin{array}{l}\text { Commu- } \\
\text { nality }\end{array}$ & Load & $\begin{array}{c}\text { Total } \\
\text { Variance }\end{array}$ \\
\hline \multirow{7}{*}{ 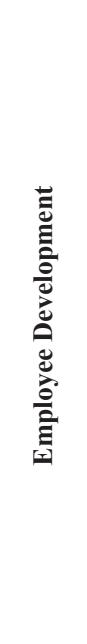 } & $\begin{array}{l}\text { Employees in your organisation are fortified enact creativ- } \\
\text { ity and perform in their specific style }\end{array}$ & .752 & .744 & \\
\hline & $\begin{array}{l}\text { Managers in your organisation give feedback on their defi- } \\
\text { ciencies to employees without hurting their ego. }\end{array}$ & .582 & .698 & \\
\hline & $\begin{array}{l}\text { The personnel policies of the organisation facilitate em- } \\
\text { ployee development. }\end{array}$ & .686 & .633 & \\
\hline & $\begin{array}{l}\text { The work situations in Infosys is welcoming and personnel } \\
\text { belief one another. }\end{array}$ & .663 & .614 & \\
\hline & $\begin{array}{l}\text { The job rotation in the organisation facilitates employee's } \\
\text { development. }\end{array}$ & .728 & .601 & \\
\hline & $\begin{array}{l}\text { Senior officer/Executive of this organisation takes active } \\
\text { attentiveness in assistants and helps learning their task. }\end{array}$ & .676 & .588 & \\
\hline & Individuals are supportive in Infosys & .379 & .428 & 44.11 \\
\hline
\end{tabular}

Journal of Technology Management for Growing Economies, Volume 9, Number 1, April 2018 


\begin{tabular}{|c|c|c|c|c|}
\hline \multirow{5}{*}{ 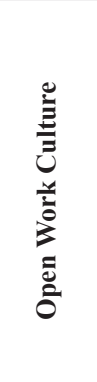 } & Employees' flaws are communicated in non-hostile mode. & .799 & .765 & \multirow[b]{4}{*}{13.37} \\
\hline & $\begin{array}{l}\text { When personnel work on his/her goal bossed take distinct } \\
\text { attention to recognize it. }\end{array}$ & .805 & 647 & \\
\hline & $\begin{array}{l}\text { The rewards are given to the employees for their better per- } \\
\text { formance \& contribution. }\end{array}$ & .696 & .632 & \\
\hline & There is high employee participation in employee appraisal & .830 & .543 & \\
\hline & $\begin{array}{l}\text { Infosys culture allows staffs express views freely, also mu- } \\
\text { tually determine solutions to common problems }\end{array}$ & .857 & .812 & \\
\hline \multirow{4}{*}{ 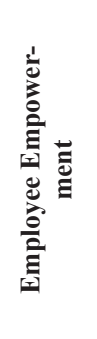 } & The team affinity is primacy in Infosys & .784 & .810 & \multirow[b]{4}{*}{6.75} \\
\hline & $\begin{array}{l}\text { Staffs in Infosys get assistance to obtain abilities and profi- } \\
\text { ciency, during performance of their task. }\end{array}$ & .701 & 692 & \\
\hline & $\begin{array}{l}\text { Delegating power to inspire workers to progress, executing } \\
\text { major accountabilities is conjoint in the businesses. }\end{array}$ & .703 & .587 & \\
\hline & $\begin{array}{l}\text { Promotion decision are grounded on the appropriateness to } \\
\text { promote instead ofprejudice }\end{array}$ & .541 & .583 & \\
\hline \multirow{2}{*}{ 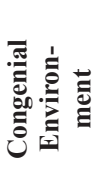 } & $\begin{array}{l}\text { Employees in your organisation are provided opportunities } \\
\text { to develop their capabilities }\end{array}$ & .735 & .818 & \multirow[b]{2}{*}{6.13} \\
\hline & $\begin{array}{l}\text { At the time of difficulties, workforces in Infosys confer } \\
\text { issues directly and efforts to resolve it instead of point the } \\
\text { finger at others }\end{array}$ & 651 & .602 & \\
\hline
\end{tabular}

An Empirical

Research on

Impact of HRD

Findings: - Factor 1 is the top most important factor which explained $44.11 \%$ of the variation. It is comprised of 7 items are extremely correlated with each other. These statements reflect HR practices towards identification and development of employees. Hence, researcher named as 'Employee development'.

$>$ Factor 2 is the most important factor which explained $13.37 \%$ of the variation. It is comprised of 5 items are highly correlated with each other. These statements reflect the reflect HR practices towards open work culture with flow of two way communication. Hence, researcher named as 'Open work Culture.

$>$ Factor 3 is the important factor which explained $6.75 \%$ of the variation. It is comprised of 4 items are highly correlated with each other. These statements reflect the reflect HR practices towards Management support and fair delegation of authority. Hence, the researcher named as 'Employee empowerment'.

$>$ Factor 4 explained $6.13 \%$ of the variation. It is comprised of 2 items are highly correlated with each other. These statements reflect HR practices towards employee encouragement and development. Hence, the researcher named as 'Congenial environment'. 
Bhambhani, G. CORRELATION ANALYSIS

Sainy, M.

Gupta, R.

Table 5: Correlation

\begin{tabular}{c|c|c|c|c|}
\hline 16 & HRD Mechanism & General Climate & $\begin{array}{c}\text { OCTAPACE } \\
\text { Culture }\end{array}$ \\
\hline HRD Mechanism & 1.00 & $.726^{* *}$ & $.687^{* *}$ \\
\hline General Climate & & 1.00 & $.834^{* *}$ \\
\hline OCTAPACE Culture & & & 1.00 \\
\hline $\begin{array}{llll}* * 2 \text { tailed Correlation at } \\
0.01 . \text { significance level }\end{array}$ & & & \\
\hline
\end{tabular}

Finding: - All three variables HRD mechanism, general climate and OCTAPACE culture are highly correlated to each other the degree of correlation lies between 0.687 to 0.834 .

\section{ONE WAY ANOVA}

Questions Is there any significant difference in HRD climate based on respondents' demographic factors?

$\mathbf{H}_{0}$ :There is no significant relationship between HRD climate dimensions and demographic variables i.e age, gender, marital status, educational qualifications, Income and Experience.

Table 6: ANOVA Test Comparing Demographic variables with HRD-Climate

\begin{tabular}{|c|c|c|c|c|c|c|c|c|}
\hline $\begin{array}{c}\text { Demographic } \\
\text { Factors }\end{array}$ & Source of Variation & $\begin{array}{c}\text { Sum of } \\
\text { Sq. }\end{array}$ & df & $\begin{array}{l}\text { Mean } \\
\text { Sq. }\end{array}$ & $\mathrm{F}$ & Sig. & & \\
\hline \multicolumn{9}{|c|}{$\mathbf{H}_{39}$ : There is no significant difference between age groups and HRD-Climate } \\
\hline \multirow{3}{*}{ Age } & Between Groups & 1.542 & 2 & .771 & \multirow{3}{*}{1.806} & \multirow{3}{*}{\multicolumn{2}{|c|}{.176}} & \multirow{3}{*}{ Accepted } \\
\hline & Within Groups & 20.062 & 47 & .427 & & & & \\
\hline & Total & 21.604 & 49 & & & & & \\
\hline \multicolumn{9}{|c|}{$\mathbf{H}_{40}$ : There is no significant difference between gender type and HRD-Climate } \\
\hline \multirow{3}{*}{ Gender } & Between Groups & 699 & 1 & .699 & \multirow{3}{*}{1.604} & \multirow{3}{*}{.011} & \multirow{3}{*}{\multicolumn{2}{|c|}{ Rejected }} \\
\hline & Within Groups & 20.906 & 48 & .436 & & & & \\
\hline & Total & 21.604 & 49 & & & & & \\
\hline \multicolumn{9}{|c|}{$\mathbf{H}_{41}$ : There is no significant difference between marital status and HRD-Climate } \\
\hline \multirow{3}{*}{ Marital status } & Between Groups & .543 & 1 & .543 & \multirow{3}{*}{1.237} & \multirow{3}{*}{.272} & \multirow{3}{*}{\multicolumn{2}{|c|}{ Accepted }} \\
\hline & Within Groups & 21.061 & 48 & .439 & & & & \\
\hline & Total & 21.604 & 49 & & & & & \\
\hline
\end{tabular}

Journal of Technology Management for Growing Economies, Volume 9, Number 1, April 2018 


\begin{tabular}{|c|c|c|c|c|c|c|c|}
\hline \multirow{3}{*}{ Education level } & Between Groups & .784 & 3 & .261 & \multirow{3}{*}{.578} & \multirow{3}{*}{.033} & \multirow[t]{3}{*}{ Rejected } \\
\hline & Within Groups & 20.820 & 46 & .453 & & & \\
\hline & Total & 21.604 & 49 & & & & \\
\hline \multicolumn{8}{|c|}{$\mathbf{H}_{43}$ : There is no significant difference between income levels and HRD-Climate } \\
\hline \multirow{3}{*}{ Income level } & Between Groups & 1.831 & 4 & .458 & \multirow{3}{*}{1.042} & \multirow{3}{*}{.396} & \multirow[t]{3}{*}{ Rejected } \\
\hline & Within Groups & 19.774 & 45 & .439 & & & \\
\hline & Total & 21.604 & 49 & & & & \\
\hline \multicolumn{8}{|c|}{$\mathbf{H}_{45}$ : There is no significant difference between experience \&HRD-Climate } \\
\hline \multirow{3}{*}{ Total Experience } & Between Groups & 1.380 & 3 & .460 & \multirow{3}{*}{1.046} & \multirow{3}{*}{.381} & \multirow[t]{3}{*}{ Accepted } \\
\hline & Within Groups & 20.224 & 46 & .440 & & & \\
\hline & Total & 21.604 & 49 & & & & \\
\hline
\end{tabular}

An Empirical

Research on

Impact of HRD

Interpretation:- The above table-26 presents the results of the one way - ANOVA test, the results show that p value for age, marital status and experience sub-dimension/ dimension are greater than 0.05 . So, we accept null hypothesis and conclude that these demographic variables have no significant relationship with HR-climate of Infosys. Whereas the p-value for gender level and education levels are less than 0.05 . So, we reject null hypothesis and conclude that these demographic variables have significant relationship with existing HR-climate of Infosys.

\section{FRIEDMEN TEST}

Question whichare the important attributes of HRD climate in Infosys?

$\mathbf{H}_{\mathbf{0}}$ : All three elements have equal impact of HR-climate in Infosys.

Table 7: Friedmen Test

\begin{tabular}{|l|l|l|l|}
\hline Elements & Mean Rank & Chi Square Value & P Value \\
\cline { 1 - 2 } General Climate & $\mathbf{2 . 0 5}$ & $\mathbf{. 0 0 0}$ & $\mathbf{. 0 2 3}$ \\
\cline { 1 - 2 } OCTAPACE culture & $\mathbf{1 . 1 8}$ & & \\
\cline { 1 - 2 } HRD Mechanisms & $\mathbf{2 . 1 4}$ & & \\
\hline
\end{tabular}

Interpretation:- The above table shows that the HRD mechanisms have prime impact on HR-climate of Infosys with mean value of 2.14, general climate 2.05 is second influencing element and OCTAPACE culture 1.18 is the least in influencing element. Thus all element don't have equal impact on HR-climate of Infosys and we reject null hypothesis and 5\% significance level.

\section{MEAN SCORE PREDICTING OVERALL HRD CLIMATE}

The element depicted in below given table express the "Overall HR-Climate" of Infosys. 
Bhambhani, G.

Table 8: Mean Scores

Sainy, M.

Gupta, R.

\begin{tabular}{|l|l|c|c|c|}
\hline $\begin{array}{l}\text { S. } \\
\text { No }\end{array}$ & Element & Mean Score & Std. Deviation & $\begin{array}{c}\text { Variance } \\
\text { Coefficient }\end{array}$ \\
\hline 1 & General Climate & 3.754 & .70403 & .496 \\
\hline 2 & OCTAPACE culture & 3.680 & .71812 & .516 \\
\hline 3 & HRD Mechanisms & 3.810 & .76266 & .441 \\
\hline & 11.244 & 2.185 & 1.453 \\
\hline & & $11.244 / 3=3.748$ & & \\
\hline
\end{tabular}

Average Mean Score $=\underline{3.754+3.680+3.810}$

3

$=3.748$

Interpretation: - The mean score of 3.748 signify overall HR-climate of Infosys is good and it is concluded that HR-climate can support for execution effective HR Programmes.

\section{RECOMMENDATIONS AND SUGGESTION}

Based on present research, it is being observed that HRD-tools i.e. work setting; rewarding system, organizational ambiance etc. have standard temperament. Where as Potential evaluation method has been observed as less effectual due to biasness that needs to be given due consideration. Thus Infosys Top management and HR professionals should make extra efforts on this factor. Superior bosses should acquire vigorous attention for development of subordinates and must dedicate spare point in time and resources towards the a like by upgrading High performers'subsequent necessary workshop and training. It facilitates association to nurture healthier interaction, collaboration, reliance and belongingness within employee at organizational level. It advances enriching atmosphere at the organizational level and lead reliable and long lasting growth.

\section{CONCLUSION}

HRD-climate enacts an extremely crucial character in victory of every business either directly or else indirectly. It influences the work activity of the personnel. If the HRD-climate is excellent, it inspires the individuals to give his/her utmost towards the successful accomplishment of corporate goals. Outcomesof contemporary research shows mean score for HRD-climate existing in Infosys is 3.748 signifies overall good and standard surrounding to work for an individual yet there is unlike spaces for enrichment in the HRD-climate. Top managing committees should look up HRD-climate by means of initiating alteration in HR

Journal of Technology Management for Growing Economies, Volume 9, Number 1, April 2018 
structure and strategies, to fulfill ever shifting want of global companies.

This research highlights that the employer and employees and relationship at organizational level has a strong bond and jointly co-coordinated. The recruits morale towards their work is highly pleased as every individual have the awareness about the various HRD polices practiced in the organization. The training programs existing in the organization's is facilitating the employees during their work.

The research was initiated to check impact of HRD-climate in Infosys. The result of the research involves 50 respondents from Infosys. The correlation analysis it has been observed that all three components HRD Mechanisms, General climate and OCTAPACE Culture are highly correlated to each other the value of $r$ is ranging lies 0.687 to 0.834 , which clearly stated that variation in single component will have strong influence on other two components. One-way anova reveals that age marital status and experience has no impact on HRD-climate of Infosys. Also, Friedmen test reveals HRD mechanisms is highly influencing element of HRD climate with mean rank of 2.14 .

Considering the sum-up of findings the research determines that employees are motivated in their organisation, there is high level of team spirit and employees are encouraged to bring creative ideas and are supported by top management of organisation

\section{LIMITATIONS \& SCOPE OF THE STUDY}

The time duration for conducting the research was short as a result of which various facts have been left unmapped. Because of time and resources scarcity conducting analysis at large level was not feasible. 50 employees answered positively. Bigger sample size could add more accuracy to the results. Certain respondents' stayed unenthusiastic to respond opinion poll due to varied reasons like bias, disinterest etc. The area for study was limited to Infosys only.

\section{ACKNOWLEDGEMENT}

This work is a part of $\mathrm{PhD}$ thesis "Human Resource Management in Information Technology Sector in India with Special reference to Madhya Pradesh" at Devi Ahilya Vishwavidyalaya, Indore, (MP) India.

\section{REFERENCE}

Armstrong, M. and Baron A (2002) "Strategic HRM: The Key to Improved Business Performance", CIPD, London.

Armstrong, M (2005) "A Hand book on Human Resources Management Practices; UK; Kogan. Adeniji, A A and Osibanjo, AO (2012) "Human Resource Management: Theory and Practice. Lagos", Pumark Nigeria Limited,

Barney, J. B. and Wright, P. M. (1998) "On becoming a Strategic Partner: The Role of HR in gaining competitive advantage”, Human Resource Management, 37:31-46. pp. 2. https://

Journal of Technology Management for Growing Economies, Volume 9, Number 1, April 2018 
Bhambhani, G. Sainy, M. Gupta, R.
doi.org/10.1002/(SICI)1099-050X(199821)37:1<31::AID-HRM4>3.0.CO;2-W.

Barney, J. (1991) "Firm resources and sustained competitive advantage", Journal of Management, 17: 99- 120.

Battu N.R. (2007) “Human Resource Development” APH publishing corporation, New Delhi. [7].

Benjamin, A. (2012) "Human Resource Development Climate as a Predictor of Citizenship Behaviour and Voluntary Turnover Intentions in the Banking Sector", International Business Research, 5(1),pp. 110-119.

Bhattacharyya D. K. (2006) "Research Methodology", Second Edition-2006, Excel Books, New Delhi.

Dolai, D. (2015), Perception of employees on HRD climate in insurance sector."4 (7), pp. 328330

Kashyap, Vaneet, Vohra, Prince, Kaur, Tejbir, Sep. ( 2012). "Comparative Analysis of Organisational Culture: The Empirical study of IT Organisations in the Region of Mohali (Panjab, India)", International Journal of Management \& Business Studies, 2(3), pp. 6064.

Kumudha, A., \& Abraham, S. (2008) "Organisation careermanagement and its impact on career satisfaction: A study in the banking sector", ICFAI University Journal of Bank Management, 7(3), 71-84.

McKenna, E. (2000) "Business Psychology and Organizational Behaviour", (3rd Edition.) Philadelphia Psychological Press.

Mishra Padamakale and Gopa Bhardwaj (2002), "HRD Climate-An Empirical Study among Private Sector Managers", Indian Journal of Industrial Relations, 38(1), pp. 66-77.

Mohanty, B, Parija, S., Sahu, G. (2012). "An Empirical Study OnHrd Climate And Its Impact On Job Performance In Private Insurance Companies In Odisha.”ZENITH International Journal of Multidisciplinary Research, 2 (5), pp. 15-28.

Mohanty, Santosh K. \&Sahoo, K. M., April (2012), "Human Resource Development Climate in IT Industry", The Indian Journal of Industrial Relations, 47(4), 657-664.

Mufeed, S.A., (2006). "The need for a focus on key elements of HRD climate in Hospitalsan Empirical study", Management of Labour Studies XLRI, Jamshedpur 31, pp. 57-65. https://doi.org/10.1177/0258042X0603100105.

Mufeed, S. A., \& Hamdani, Q. A. (2013) "HRD mechanisms in health care sector in Jammu \& Kashmir: A comparative study", European scientific journal, 9(21).

Pillai, P. R. (2008), "Influence of HRD Climate on the Learning Orientation of Bank Employees", Indian Journal of Industrial Relations, 43 (3), pp. 406-18.

Prof. IK. Kilam (2012), "Career Planning and HRD Climate- A Major HR Challenge for Public Sector Banks in India", Asian Journal of Multidimensional Research, I(7). pp. 60-82.

Purang, P. (2008) "Dimensions of HRD Climate Enhancing Organizational Commitment In Indian Organizations", Indian Journal of Industrial Relations, 43(4), pp. 324-333.

Rao N.P. (1992): Education and Human Resource Management .APH Pub. New Delhi pp. $1-263$.

Rao P Subba, "Human Resource Management?", First Edition-2010, Himalaya Publishing House.

Rao, TV. and E. Abraham (1986) "HRD Practices in Indian Industries: A Trend Report.11, Vol.2: Management and Labour Studies, April.

Sampson, W.R. (2005) "Influences on Employee Behaviour Part I. [Online] Available: http:// www.uwec.edu/Sampsow/350/2005a/PowerPoints/350-05-03-15_files/frame.htm (April 5, 2010).

Samantaray, P.C. (2007): “Co-operative and HRD” Indian Consumer Co-operator, July -Sept. 2007.

Saraswathi , S., (2010) "Human Resources Development Climate: An Empirical Study",

Journal of Technology Management for Growing Economies, Volume 9, Number 1, April 2018 
International Journal of Innovation Management and Technology, 1(2), pp. 174-179.

Sharma, A and Purang, P., (2000), "Value Institutionalization and HRD Climate: A Case Study of a Navratna Public Sector Organisation”, Vision-The Journal of Business Perspective, 4 ,pp. 11-17.

Shweta Mittal (2013), HRD climate in public and private sector banks, The Indian Journal of Industrial Relation, 49(1), pp. 123-131

Salokhe, A., \&Chaudhary, N. (2010) "HRD Climate andOrganizational Performance with focus on Job Satisfaction as a Correlate: Exploratory Analysis", TECNIA Journal of Management Studies, 47.

Srimannarayana, M (2007), "Human Resource Development Climate in a Dubai Bank", ICFAI Journal of Organizational Behaviour, 6(1), pp. 33-40.

Wani, T. A. (2013) "An Empirical Study of HRD Climate and OCTAPAC Culture in FMCG Companies in India, international monthly referred journal of research in management and technology, 2, pp. 100-106.

\section{An Empirical \\ Research on \\ Impact of HRD}

